\title{
Pengaruh Dosis Bokashi Serbuk Gergaji terhadap Pertumbuhan dan Hasil Tanaman Mentimun Jepang (Cucumis sativus L.) pada Tanah Gambut
}

\section{(The Effect of Saw Powder Bokashi Dosage to Growth and Yield Japanese Cucumber (Cucumis sativus L.) on Peatland)}

\author{
Yulianti Hidayah \\ Program Studi Pendidikan Biologi STKIP PGRI Banjarmasin \\ yuliantihidayah79@gmail.com
}

\begin{abstract}
ABSTRAK
Lahan gambut berpotensi dijadikan pengembangan tanaman pertanian walupun ditemui sejumlah kendala seperti sifat kimia, fisik, dan biologi tanah. Kendala sifat kimia seperti pH rendah, C/N ratio tinggi, kandungan $P, K, C a$ dan $M g$ yang rendah. Usaha untuk meningkatkan $p H$ tanah dan kesuburan tanah dengan pemupukan. Bokashi merupakan pupuk organik yang dibuat menggunakan teknologi efektif mikroorganisme. Tujuan penelitian (i) mengetahui pengaruh dan (ii) mendapatkan dosis terbaik bokashi serbuk gergaji terhadap pertumbuhan dan hasil tanaman mentimun Jepang pada tanah gambut. Dilaksanakan di Rumah Kaca Fakultas Pertanian Unlam Banjarbaru pada bulan Maret - Juni 2002, menggunakan Rancangan Acak Lengkap (RAL) faktor tunggal. Faktor yang diteliti adalah perlakuan dosis bokashi serbuk gergaji (B) sebanyak tujuh taraf yaitu $b_{1}=2,5$ t.ha ${ }^{-1}, b_{2}=5$ t.ha $a^{-1}, b_{3}=$ 7,5 t.ha ${ }^{-1}, b_{4}=10$ t.ha ${ }^{-1}$ dan $b_{5}=12,5 t \cdot h a^{-1}, b_{6}=15,0$ t.hat ${ }^{-1}, b_{7}=17,5 t \cdot h^{-1}$. Peubah yang diamati adalah tinggi tanaman umur 14, 21, 28, 35 dan 42 hari setelah tanam (HST), umur berbunga pertama, saat buah pertama terbentuk, saat panen pertama, panjang buah, diameter buah, jumlah buah per tanaman dan berat buah per tanaman. Perlakuan tidak berpengaruh terhadap peubah tinggi tanaman pada umur 14, 21, 28, 35 dan 42 HST, saat berbunga pertama, saat terbentuk buah pertama, saat panen pertama, diameter buah dan jumlah buah per tanaman. Tetapi perlakuan berpengaruh terhadap peubah berat buah per tanaman dan panjang buah, dengan perlakuan terbaik 12,5 t.ha ${ }^{-1}$ memberikan hasil berat buah per tanaman dan panjang buah terbaik.
\end{abstract}

Kata kunci: Serbuk, gergaji, mentimun, Jepang, gambut.

\section{ABSTRACT}

Peatlands have the potential to be used as agricultural development even though a number of obstacles are encountered, such as the chemical, physical and biological characteristics of the soil. Chemical constraints such as low $\mathrm{pH}$, high $\mathrm{C} / \mathrm{N}$ ratio, low $\mathrm{P}, \mathrm{K}, \mathrm{Ca}$ and $\mathrm{Mg}$ content. Efforts to increase soil $\mathrm{pH}$ and soil fertility by fertilizing. Bokashi is an organic fertilizer made using effective microorganism technology. The aim of the study (i) is to know the effect and (ii) to get the best dosage of sawdust bokashi on the growth and yield of Japanese cucumber plants on peat soil. Implemented in the Greenhouse Faculty of Agriculture Unlam Banjarbaru in March - June 2002, using a single Randomized Complete Design (CRD) factor. The factors studied were the treatment of sawdust bokashi dose (B) as many as seven levels, namely $b_{1}=2.5$ t.ha ${ }^{-1}, b_{2}=5$ t.ha ${ }^{-1}, b_{3}=7.5 t . h a^{-1}, b_{4}=10 t . h a^{-1}$ and $b_{5}=12.5$ t.ha ${ }^{-1}, b_{6}=15.0$ t.hat,$b_{7}=17.5$ t. $h^{-1}$. The variables observed were plant height aged 14, 21, 28, 35 and 42 days after planting (DAP), the age of the first flowering, when the first fruit was formed, at the first harvest, fruit length, fruit diameter, number of fruits per plant and weight per fruit. plant. The treatment had no effect on plant height variables at ages 14,21,28, 35 and 42 DAP, when the first flowering, when the first fruit was formed, at the first harvest, fruit diameter and number of fruits per plant. But the treatment affected the fruit weight per plant and fruit length, with the best treatment 12.5 t.ha $a^{-1}$ yielding the best fruit weight per plant and fruit length.

Keywords: Powder, saws, cucumber, Japan, peat.

\section{PENDAHULUAN}

Tanaman Hortikultura

terutama sayuran merupakan komoditas pertanian yang dimanfaatkan sebagai bahari pangan penting. Dan sayuran cukup banyak dihasilkan protein, vitamin, dan mineral. 
Dengan demikian diharapkan sayuran berperan penting bagi kesehatan. Selain itu juga savuran akan senantiasa meningkatkan pendapatan petani, devisa negara, perluasan kesempatan kerja bahkan dapat berperan aktif dalam program pengentasan kemiskinan (Sunaryono, 1984).

Salah satu upaya untuk meningkatkan persediaan sayuran adalah dengan meningkatkan produksi mentirnun. Mentimun adalah salah satu sayuran buah yang banyak diusahakan petani dalam berbagai skala usaha tani, baik untuk keperluan pasar tradisional, swalayan, ekspor, bahkan untuk bahari baku industri dan obat-obatan (Sumpena, 2001).

Pada saat ini salah satu jenis mentimun yang sedang gencar dibudidayakan adalah mentimun Jepang. Mentimun Jepang memiliki karakteristik yang berbeda dibanding mentimun Iainnya. Sosoknya pun sedikit berbeda, lebih panjang, paling lembut daging buahnya, dan paling halus kulitnya dibandingkan jenis mentimun lainnya yang banyak mengandung air, rasanya lebih manis, lebih renyah, bentuknya lebih ramping dan warnanya lebih hijau (Setiawan, et. al., 1993).

Untuk menghasilkan mentimun khususnya mentimun Jepang yang berkualitas baik, maka segalanya diimbangi dengan upaya meningkatkan produksi secara intensif, termasuk memanfaatkan lahan yang kurang subur seperti halnya tanah gambut sebagal akibat tetjadinya pergeseran tata guna lahan.

Lahan gambut berpotensi besar untuk dijadikan areal pengembangan tanaman pertanian walupun masih ditemui sejumlah kendala seperti sifat kimia, fisik, dan biologi tanah. Kalau dilihat dan sifat kimia yang kurang mendukung pertumbuhan tanaman seperti $\mathrm{pH}$ rendah, $\mathrm{C} / \mathrm{N}$ ratio tinggi, kandungan $\mathrm{P}, \mathrm{K}, \mathrm{Ca}$ dan $\mathrm{Mg}$ yang rendah, drainase buruk dan lingkungan yang selalu tergenang air sehingga pelapukan kurang sempuma mengakibatkan produktivitasnya rendah dan untuk meningkatkan produktivitas gambut perlu dilaksanakan pengapuran, pemberian pupuk organik, dan pengelolaan air (Halim,
1987 ; Subiksa, 1996 dalam Sudirman, 1999).

Sejalan dengan usaha menemukan cara-cara untuk meningkatkan $\mathrm{pH}$ tanah dan kesuburan tanah, pemupukan merupakan salah satunya. Pemupukan merupakan hal penting bagi kehidupan tanaman dan hasil yang didapat. Pemupukan dapat dilakukan baik dengan menggunakan pupuk anorganik maupun pupuk organik.

Pupuk organik adalah pupuk yang berasal dan pelapukan sisa-sisa mahluk hidup seperti tanaman dan hewan. Dalam proses perombakan pupuk organik menjadi senyawa anorganik yang tesedia bagi tanaman memerlukan waktu relatif lama sampai berbulan - bulan. Namun dengan adanya teknologi baru yaitu teknologi fermentasi dengan memanfaatkan "Effective Microorganisme" $\left(\mathrm{EM}_{4}\right)$, perombakan bahan-bahan tersebut dapat dilakukan dalam waktu yang lebih singkat (Soeseno, 1998).

Efective Microorganisme $\left(\mathrm{EM}_{4}\right)$ yang dipergunakan dalam fermentasi ini secara fisik dapat menggemburkan tanah, sehingga lapisan olah menjadi dalam dan ruang gerak akar menjadi bertambah luas, secara kimia akan dapat membawa $\mathrm{pH}$ tanah kearah normal sehingga ketersediaan unsur hara menjadi semakin mudah bagi perakaran tanaman, sedangkan secara biologis dapat meningkatkan populasi mikroorganisme fermentasi sintetik sehingga pertumbuhan penyakit dan serangga dapat ditekan (Wididana, 1998).

Hasil fermentasi bahan organik dengan teknologi EM4, dinamakan bokashi. Bokashi banyak mengandung senyawa organik seperti asam amino, protein, gula, alkohol dan mikroorganisme fermentasi serta sintesis, mengandung mikroorganisme yang menguntungkan yang telah hidup dan berkembang di dalam bahan organik, sehingga jika bokashi disebarkan ke dalam tanah, EM akan mudah dan cepat berkembang biak (Higa, 1991).

Serbuk gergaji merupakan salah satu bahan yang dapat dibuat bokashi yang belum dimanfaatkan secara optimal oleh petani. Dengan menggunakan serbuk gergaji selain harganya murah juga mudah didapatkan. 
Dan hasil analisis kimia pada serbuk gergaji Meranti (Shorea sp) yang telah mengalami perlakuan penyimpanan selama tiga bulan, serbuk gergaji meranti memiliki kandungan unsur hara makro dan mikro yang dibutuhkan untuk pertumbuhari tanaman dan juga memiliki aerasi dan drainase yang baik (Rismayani, 1987 dalam Parjiono, 2001).

Pemberian bahan organik pada tanah gambut dengan tujuan meningkatkan kesuburan tanah terutama untuk meningkatkan $\mathrm{pH}$ tanah agar dapat memenuhi kebutuhari hara tanaman supaya dapat tumbuh dengan baik sangat ditentukan oleh bahan organik yang diberikan. Berdasarkan hal tersebut maka perlu dilakukan penelitian tentang jumlah bahan organik yang akan diberikan dalam hai ini dosis bokashi serbuk gergaji terhadap pertumbuhan dan hasil tanaman mentimun Jepang pada tanah gambut.

Tujuan penelitian ini adalah (i) mengetahui pengaruh dosis bokashi serbuk gergaji terhadap Pertumbuhan dan hasil tanaman mentimun Jepang pada tanah gambut dan (ii) untuk mendapatkan dosis bokashi serbuk gergaji yang terbaik terhadap pertumbuhan dan hasil tanaman mentimun Jepang pada tanah gambut.

\section{BAHAN DAN METODE}

Penelitian ini menggunakan rancangan Acak Lengkap (RAL) faktor tunggal. Faktor yang diteliti adalah dosis bokashi serbuk gergaji (B) sebanyak tujuh perlakuan seperti terlihat pada Tabel 1 dan ulangan sebanyak tiga kali.

Tabel 1. Perlakuan bokashi serbuk gergaji.

\begin{tabular}{|c|c|c|}
\hline No. & Perlakuan & Dosis \\
\hline 1. & $\mathrm{~b}_{1}$ & 2,5 ton ha $^{-1}$ setara dengan 125 gram.polybag ${ }^{-1}$ \\
\hline 2. & $\mathrm{~b}_{2}$ & 5 ton ha $^{-1}$ setara dengan 250 gram.polybag ${ }^{-1}$ \\
\hline 3. & $b_{3}$ & 7,5 ton ha $^{-1}$ setara dengan 375 gram.polybag $^{-1}$ \\
\hline 4. & $\mathrm{~b}_{4}$ & 10,0 ton ha ${ }^{-1}$ setara dengan 500 gram.polybag ${ }^{-1}$ \\
\hline 5. & $\mathrm{~b}_{5}$ & 12,5 ton $\mathrm{ha}^{-1}$ setara dengan 625 gram.polybag ${ }^{-1}$ \\
\hline 6. & $\mathrm{~b}_{6}$ & 15,0 ton $\mathrm{ha}^{-1}$ setara dengan 750 gram.polybag ${ }^{-1}$ \\
\hline 7. & $\mathrm{~b}_{7}$ & 17,5 ton ha $^{-1}$ setara dengan 875 gram.polybag ${ }^{-1}$ \\
\hline
\end{tabular}

\section{Pelaksanaan Penelitian}

Penelitian ini dilaksanakan di Rumah Kaca Fakultas Pertanian Unlam Banjarbaru. Pelaksanaan terdiri dari uji daya kecambah, persemaian, persiapan media, pengapuran. penanaman, pemupukan, pemeliharaan dan pemanenan. Pengamatan yang dilakukan adalah pengukuran peubah tinggi tanaman, umur tanaman saat berbunga, saat terbentuk buah, saat panen pertama, panjang buah, diameter buah, jumlah buah per tanaman dan berat buah per tanaman.

Setelah data diperoleh untuk mengetahui ada tidaknya pengaruh beberapa tingkat dosis bokashi serbuk gergaji terhadap peubah yang diamati maka dilakukan analisis ragam dengan menggunakan uji $\mathrm{F}$ pada taraf uji I \% dan uji $\mathrm{F}$ taraf uji $5 \%$. Bila hasil uji $\mathrm{F}$ berbeda nyata atau sangat nyata maka dilanjutkan dengan uji beda nilai tengah dengan menggunakan uji DMRT pada taraf uji $5 \%$.

\section{HASIL DAN PEMBAHASAN}

\section{Tinggi tanaman}

\section{Hasil}

Berdasarkan analisis ragam menunjukkan bahwa perlakuan dosis bokashi serbuk gergaji tidak berpengaruh terhadap tinggi tanaman umur 14, 21, 28, 35 dan 42 HST.

\section{Umur tanaman saat berbunga pertama}

Data pengamatan saat berbunga pertama berdasarkan analisis ragamnya menunjukkan bahwa perlakuan dosis bokashi serbuk gergaji tidak berpengaruh 
terhadap peubah umur saat berbunga pertama.

\section{Saat terbentuk buah pertama}

Data pengamatan saat terbentuk buah pertama berdasarkan analisis ragamnya menunjukkan bahwa perlakuan dosis bokashi serbuk gergaji bokashi serbuk gergaji tidak berpengaruh terhadap peubah saat terbentuk buah pertama.

\section{Saat panen pertama}

Berdasarkan analisis ragamnya menunjukkan bahwa perlakuan dosis bokashi serbuk gergaji tidak berpengaruh terhadap peubah saat panen pertama.

\section{Panjang buah}

Berdasarkan analisis ragamnya menunjukkan bahwa perlakuan dosis bokashi serbuk gergaji berpengaruh nyata terhadap peubah panjang buah.

Hasil uji beda nilai tengah pengaruh perlakuan dosis bokashi serbuk gergaji terhadap peubah panjang buah dapat dilihat pada Tabel 2.

Tabel 2. Hasil uji beda nilai tengah pengaruh perlakuan dosis bokashi serbuk gergaji terhadap peubah panjang buah.

\begin{tabular}{|c|c|}
\hline Perlakuan $\left(\mathrm{t} \mathrm{ha}^{-1}\right)$ & Panjang buah $(\mathrm{cm})$ \\
\hline $\mathrm{b}_{1}\left(2,5\right.$ ton $\left.\mathrm{ha}^{-1}\right)$ & $36,97^{\mathrm{ab}}$ \\
\hline $\mathrm{b}_{2}\left(5,0\right.$ ton $\left.\mathrm{ha}^{-1}\right)$ & $31,20^{\mathrm{a}}$ \\
\hline $\mathrm{b}_{3}\left(7,5\right.$ ton $\left.\mathrm{ha}^{-1}\right)$ & $35,10^{\mathrm{a}}$ \\
\hline $\mathrm{b}_{4}\left(10,0\right.$ ton $\left.\mathrm{ha}^{-1}\right)$ & $40,70^{\mathrm{abc}}$ \\
\hline $\mathrm{b}_{5}\left(12,5\right.$ ton $\left.\mathrm{ha}^{-1}\right)$ & $67,70^{\mathrm{d}}$ \\
\hline $\mathrm{b}_{6}\left(15,0\right.$ ton $\left.\mathrm{ha}^{-1}\right)$ & $62,60^{\mathrm{cd}}$ \\
\hline $\mathrm{b}_{7}\left(17,5\right.$ ton $\left.\mathrm{ha}^{-1}\right)$ & $59,80^{\text {bcd }}$ \\
\hline
\end{tabular}

Keterangan : Nilai rata-rata yang ditandai huruf yang sama berarti tidak berbeda nyata menurut DMRT $5 \%$.

\section{Diameter buah}

Berdasarkan hasil analisis ragam menunjukkan bahwa perlakuan dosis bokashi serbuk gergaji tidak berpengaruh terhadap peubah diameter buah.

\section{Jumlah buah per tanaman}

Berdasarkan analisis ragamnya menunjukkan bahwa perlakuan dosis bokashi serbuk gergaji tidak berpengaruh terhadap peubah jumlah buah per tanaman.

\section{Berat buah per tanaman}

Berdasarkan analisis ragamnya menunjukkan bahwa perlakuan dosis bokashi serbuk gergaji berpengaruh sangat nyata terhadap peubah berat buah per tanaman.

Hasil uji beda nilai tengah pengaruh perlakuan dosis bokashi serbuk gergaji terhadap peubah berat buah per tanaman dapat dilihat pada Tabel 3. 
Tabel 3. Hasil uji beda nilai tengah pengaruh dosis bokashi serbuk gergaji terhadap peubah berat buah per tanaman.

\begin{tabular}{cc}
\hline Perlakuan $\left(\mathrm{t} \mathrm{ha}^{-1}\right)$ & Berat buah per tanaman $(\mathrm{g})$ \\
\hline b1 $\left(2,5\right.$ ton ha- $\left.\mathrm{ha}^{-1}\right)$ & $236,20 \mathrm{a}$ \\
b2 $\left(5,0\right.$ ton $\left.\mathrm{ha}^{-1}\right)$ & $209,45 \mathrm{a}$ \\
b3 $\left(7,5\right.$ ton $\left.\mathrm{ha}^{-1}\right)$ & $233,44 \mathrm{a}$ \\
b4 $\left(10,0\right.$ ton ha $\left.\mathrm{ha}^{-1}\right)$ & $314,93 \mathrm{ab}$ \\
b5 $\left(12,5\right.$ ton ha $\left.\mathrm{ha}^{-1}\right)$ & $435,44 \mathrm{~b}$ \\
b6 $\left(15,0\right.$ ton $\left.\mathrm{ha}^{-1}\right)$ & $429,87 \mathrm{~b}$ \\
b7 $\left(17,5\right.$ ton ha $\left.\mathrm{ha}^{-1}\right)$ & $433,81 \mathrm{~b}$ \\
\hline
\end{tabular}

Keterangan : Nilai rata-rata yang ditandai huruf yang sama berarti tidak berbeda Nyata menurut uji DMRT 5\%.

\section{Pembahasan}

Hasil penelitian memperlihatkan bahwa perlakuan dosis bokashi serbuk gergaji menunjukkan pengaruh nyata terhadap peubah panjang buah dan berat buah per tanaman, sedangkan terhadap peubah tinggi tanaman, umur tanaman saat berbunga pertama, saat terbentuk buah pertama, saat panen pertama, diameter buah dan jumlah buah per tanaman tidak berpengaruh.

Hasil penelitian memperlihatkan bahwa perlakuan dosis bokashi serbuk gergaji tidak berpengaruh terhadap peubah tinggi tanaman pada umur 14, 21, 28, 35 dan 42 hari setelah tanam (HST). Tidak berpengaruhnya dosis bokashi serbuk gergaji terhadap peubah tinggi tanaman pada umur 14, 21, 28, 35 dan 42 HST diduga karena unsur hara yang terdapat pada bokashi serbuk gergaji terutama unsur $\mathrm{N}$ belum sepenuhnya dapat diserap tanaman karena proses penguraian bokashi menjadi bentuk yang tersedia bagi tanaman berjalan dengan lambat dan diduga bahan organik yang terkandung didalamnya, terutama bahari organik dalam tanah gambut, belum sepenuhnya terdekomposisi yang hal ini sejalan dengan pendapat Wididana (1994) yang mengatakan bahwa kecepatan dekomposisi bahan organik tidak seiring dengan pertumbuhan tanaman. Unsur $\mathrm{N}$ yang tidak terdekomposisi secara sempurma menyebabkan perbentukan kiorofil daun terhambat dan proses fotosintesis juga akan terhambat yang pada akhirnya pertumbuhan tanaman akan terhambat pula (Buckman dan
Brady, 1982). Hal ini sesuai pula dengan penelitian Fitri, 2002) bahwa penambahan dosis bokashi jerami padi tidak berpengaruh terhadap tinggi tanaman cabai rawit pada umur 14, 21, 28, 35 dan 42 HST pada tanah gambut. Faktor lain yang mempengaruhi adalah faktor kualitas cahaya, dimana panjang gelombang yang dapat diserap oleh tanaman adalah panjang gelombang pendek yang bila menembus suatu benda, penelitian dilaksanakan di rumah kaca, maka akan berubah menjadi panjang gelombang panjang. Bilamana panjang gelombang panjang diserap tanaman, maka akan mengalami etiolasi, dan dengan terjadi etiolasi maka zat makanan banyak digunakan untuk pertumbuhan memanjang (Dwidjoseputro, 1994).

Hasil penelitian memperlihatkan bahwa perlakuan dosis bokashi serbuk gergaji menunjukkan bahwa tidak ada pengaruh terhadap peubah tanaman saat berbunga pertama dan saat terbentuk buah. Tidak berpengaruhnya dosis bokashi serbuk gergaji terhadap peubah saat berbunga pertama dan saat terbentuk buah pertama disebabkan pentumbuhan dan perkembangan tanaman baik pada fase vegetatif maupun fase generatif, tergantung dan faktor genetik dan faktor lingkungan. Faktor genetik berasal dan tanaman itu sendiri, sedangkan faktor Iingkungan terutama faktor temperatur, kelembaban udara dan curah hujan. Pada temperatur yang tinggi dapat mengakibatkan media tanam lebih cepat mengalami kekeringan, sehingga dapat mengakibatkan bunga dan bakal buah menjadi mudah rontok (Tim 
Redaksi Trubus, 1990). Rukmana (1994) menyebutkan bahwa temperatur yang sesuai untuk menyeimbangkan tanaman mentimun adalah daerah dengan temperatur $21,5^{\circ} \mathrm{C}$, sedangkan pada saat penelitian temperaturnya $27^{\circ} \mathrm{C}$. Tidak berpengaruhnya umur tanaman saat berbunga pertama didukung oleh penelitian Noor (2001) bahwa perlakuan bokashi kotoran ayam tidak berpengaruh terhadap umur tanaman saat berbunga pertama tanaman tomat pada tanah podsolik dan penelitian Hendrawati (2002) bahwa perlakuan dosis bokashi guano tidak berpengaruh terhadap umur tanaman saat berbunga pertama tanaman lombok merah pada tanah gambut. Data temperatur dan kelembaban udara.

Hasil penelitian memperlihatkan bahwa perlakuan dosis bokashi serbuk gergaji tidak berpengaruh terhadap peubah saat panen pertama. Hal ini diduga adanya pengaruh faktor genetis tanaman disamping keberhasilan bunga menjadi buah dipengaruhi oleh lingkungan tumbuh dan aktifitas serangga dalam membantu proses penyerbukan karena tanaman mentimun tidak bisa melakukan penyerbukan sendiri tetapi harus melalui penyerbukan silang. Hal ini dudukung oleh penelitian Hidayat (2000) dimana pengaruh pemberian pupuk bokashi jerami padi terhadap pertumbuhan dan hasil tanaman mentimun Jepang tidak memberikan pengaruh yang nyata terhadap peubah saat panen pertama tanaman mentimun Jepang pada tanah podsolik.

Hasil penelitian rnemperlihatkan bahwa dosis bokashi serbuk gergaji tidak memberikan pengaruh terhadap peubah diameter buah. Tidak berpengaruhnya peubah diameter buah ini diduga unsur hara lebih dominan digunakan untuk pemanjangan buah apalagi kalau dihubungkan dengan media tanam dengan polybag dimana pada suatu saat kandungan unsur haranya menipis dan bahkan akan habis. Hal ini didukung oleh penelitian Noor (2002) dimana pengaruh takaran bokashi enceng gondok terhadap pertumbuhan dan basil waluh tidak memberikan pengaruh yang nyata terhadap peubah diameter buah waluh pada tanah gambut.
Hasil penelitian memperlihatkan bahwa perlakuan dosis bokashi serbuk gergaji tidak berpengaruh terhadap peubah jumlah buah per tanaman. Tidak berpengaruhnya dosis bokashi serbuk gergaji terhadap peubah jumlah buah pertanaman ini berkaitan dengan faktor lingkungan yaitu iklim yang dapat menjadi faktor pembatas dalam pertumbuhan dan perkembangan tanaman. Penelitian ini dilaksanakan pada awal musim hujan dimana curah hujan yang tinggi mengakibatkan intensitas serangan harna dan penyakit tinggi. Walaupun bunga yang menjadi buah banyak dihasilkan, tetapi akibat serangan lalat buah (Dacus spp) dan penyakit layu bakteri (Erwinia iracheiphila) maka buah yang sertahari sampai panen sangat sedikit. Lalat buah menyerang dengan jalan menusuk dan menghisap cairan buah, sehingga buah yang diserangnya menjadi busuk, dan penyakit Iayu bakteri dimana ditandai dengan kelayuan pada seluruh daun secara mendadak, sehingga tanaman mati (Rukmana, 1994).

Hasil penelitian memperlihatkan bahwa perlakuan dosis bokashi serbuk gergaji 12,5 t. ha ${ }^{-1}$ menunjukkan pengaruh yang nyata terhadap peubah berat buah per tanaman dan panjang buah. Hal ini diduga kebutuhan unsur hara terutama posfor dan kalium sudah terpenuhi untuk mendukung berpengaruhnya berat buah per tanaman dan panjang buah. Setyamidjaja (1986) menyebutkan bahwa semakin banyak fosfor yang diserap tanaman, maka metabolisme tanaman akan meningkat seperti peningkatan fotosintesis, yang menghasilkan fotosintat yang dihasilkan oleh tanaman juga sertambah. Fotosintat ditranslokasikan melalui pembuluh tapis (floem) ke jaringan penumpukan seperti buah dan biji yang mengakibatkan unsur yang penting adalah kalium dimana kalium berfungsi dalam memperkuat tubuh tanaman agar daun, bunga dan buah tidak mudah gugur (Lingga, 1995), selain berfungsi dalam pembentukan karbohidrat, protein dan mempengaruhi penyerapan unsur lain (Hardjowigeno, 1987). Disamping ketersediaan unsur hara, pembenan bokashi juga mempengaruhi sifat 
Yulianti Hidayah, Pengaruh dosis serbuk gergaji terhadap pertumbuhan...

fisik tanah yaitu memperbaiki aerasi dan drainase tanah sehingga respon tanaman menjadi lebih baik (Kohke, 1968 dalam Winarno, 2000). Selain itu juga mempengaruhi sifat kimia tanah dengan meningkatkan ketersediaan unsur hara nitrogen, fosfat dan kalium serta $\mathrm{pH}$ tanah sehingga unsur hara menjadi lebih mudah tersedia bagi tanaman. dan mempengaruhi sifat biologi yang dapat meningkatkan aktivitas mikroorganisme tanah seperti bakteri asam laktat, bakteri fotosintetik, actinomycetes, ragi, jamur dan bakteri pelarut fosfat yang hermanfaat bagi tanaman (Higa, 1991). Faktor lain yang mempengaruhi berpengaruhnya dosis serbuk gergaji terhadap peubah berat buah per tanaman dan panjang buah adalah adanya ketersediaan air yang cukup dimana menurut Darjanto (1982), untuk pertumbuhan buah diperlukan banyak air, karena buah yang rnasih muda mengandung banyak air yang kadang-kadang sampai $85 \%$. Selain itu ketersediaan air yang cukup sangat berpengaruh terhadap proses-proses metabolisme, fotosintesis, respirasi dan proses Iainnya dalam tubuh tanaman (Sarief, 1985). Hasil penelitian Parjiono (2001) menunjukkan bahwa pemberian bokashi serbuk gergaji terhadap pertumbuhan dan hasil tanaman sawi pada tanah podsolik memberikan pengaruh yang nyata terhadap peubah berat segar per tanaman.

\section{KESIMPULAN}

Perlakuan dosis bokashi serbuk gergaji tidak berpengaruh terhadap peubah tinggi tanaman pada umur 14, 21, 28, 35 dan 42 HST, saat berbunga pertama, saat terbentuk buah pertama, saat panen pertama, diameter buah dan jumlah buah per tanaman. Tetapi dosis bokashi serbuk gergaji berpengaruh terhadap peubah berat buah per tanaman dan panjang buah. Pada perlakuan dosis bokashi serbuk gergaji 12,5 t.ha ${ }^{-1}$ memberikan hasil berat buah per tanaman dan panjang buah terbaik.

\section{DAFTAR PUSTAKA}

Buckman, H.O dan Brady, N.C. 1982. Ilmu Tanah. PT. Bhratara Karya Aksara. Jakarta. 788 Hal.

Daryanto dan Satifah. 1982. Biologi Bunga dan Teknik Penyerbukan Silang Buatan. Gramedia. Jakarta.

Dwidjoseputro. 1994. Pengantar Fisiologi Tanaman. PT Grarnedia. Jakarta. Hal 11-15.

Fitri, N. 2002. Pengaruh Dosis Bokashi Jerami Padi terhadap Pertumbuhan dan hasil Tanaman Cabai Rawit (Capsicum frutescents L.) pada Tanah Gambut. Skripsi Fakultas Pertanian Unlam. Banjarbaru. Hal 30.

Hardjowigeno, S. 1987. ilmu Tanah. Mediyatama. Sarana Perkasa. Jakarta. 218 Hal.

Hendrawati, E. 2002. Pengaruh Dosis Bokashi Guano terhadap Pertumbuhan dan Hasil Tanaman Lombok Merah (Capsicum annum L.) pada Tanah Gambut. Skripsi Fakultas Pertanian Unlam. Banjarbaru.

Hidayat, W., Hegar. 2000. Pengaruh Pemberian Dosis Bokashi Jerami Padi terhadap Pertumbuhan dan Hasil Tanaman Mentimun Jepang (Cucumis sativus L.). Skripsi Fakultas Pertanian Unlam. Banjarbaru. Hal 32.

Higa dan Wididana. 1991. Concept and Theories Of Effective Microorganism Page $118-124$ In J.F.Parr; SB. Ornick, C.E. Whitman (eds) First I International Confence at Khon Khaen. Khon Kaen Thailand. October 7-21 1989.

Lingga, P. 1995. Petunjuk Penggunaan Pupuk. Penebar Swadaya. Jakarta. 
Noor, A. 2001. Respon tanaman tomat (lycopersicum escuentum) varietas ratria terhadap dosis bokashi kotoran ayam dan pupuk cair green tonic pada tanah gambut. Skripsi Fakultas Pertanian Unlam. Banjarbaru.

Noor, M. 2002. Pengaruh takaran bokashi enceng gondok terhadap pertumbuhan dan hasil tanaman waluh (Cucurbita moschata ex.Pair) pada tanah gambut. Skripsi Fakultas Pertanian Unlam. Banjarbaru.

Parjiono. 2001. Pengaruh dosis bokashi serbuk gergaji dan urea terhadap pertumbuhan dan hasil tanaman sawi. Skripsi Fakultas Pertanian Unlam. Banjarbaru.

Rukmana, R. 1994 Budidaya Mentimun Kanisius. Yogyakarta.

Sarief, S. 1985. Ilmu Tanah Pertanian. Pustaka Buana. Bandung.

Setiawan, I.A. 1993. Sayuran Dataran Tinggi. Penebar Swadaya. Jakarta.

Setyamidjaja, D. 1986. Pupuk dan Pemupukan. CV. Simplex. Jakarta.

Soeseno, S. 1998. Untuk Apa Mereka Memakai Bokashi?. Trubus No.346. Tb XXI. september 1998. Penebar Swadaya. Jakarta. Hal 58-61.
Sudirman. 1999. Pengaruh pemberian tanah mineral dan dolomit terhadap beberapa sifat kimia gambut dan pertumbuhan tanaman jagung. Skripsi Fakultas Pertanian Unlam. Banjarbaru.

Sumpena, U. 2001. Budidaya Mentimun Intensif. Penebar Swadaya. Jakarta.

Sunaryono, H. 1984. Kunci Bercocok Tanam Sayur-sayuran Penting di Indonesia. CV. Sinar Baru. Bandung.

Tim Redaksi Trubus. 1990. Memproses Sampah. Penerbit Penebar Swadaya. Jakarta.

Wididana. 1994. Peranan Effective Microorganism 4 (EM4) Dalam Meningkatkan Kesuburan dan Produktivitas Tanah. Indonesian Kyusei Nature Farming Socities. Jakarta.

Wididana. 1998. Bokashi dan Fermentasi Apa Sih?. Institut Pengembangan Sumber Daya Alam (IPSA). Jakarta.

Winarno. 2000. Respon pertumbuhan dan hasil tanaman jagung (Zea mays L.) Varites Bisi-2 terhadap dosis pupuk kandang kotoran ayam dan Effective Microorganism 4 (EM4). Skripsi Fakultas Pertanian Unlam. Banjarbaru. 